\section{Nyttig lærebok i psykiatri}

Herlofson J, Ekselius L, Lundh L-G et al, red. Psykiatri

746 s, tab, ill. Lund: Studentlitteratur, 2009

Pris SEK 712

ISBN 978-91-44-04026-4

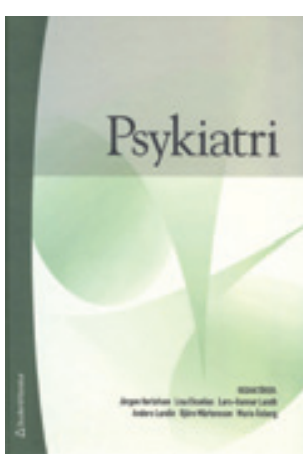

Målgruppen for denne svenske boken er medisinske studenter. Den består av hele 50 kapitler som er skrevet av enda flere forskjellige forfattere. De viktigste diagnostiske grupper er omtalt, og fremstillingen er krydret med

kortfattede og noen ganger lengre, men illustrerende kliniske vignetter. I tillegg er det blant annet oversiktskapitler om genetikk, nevrovitenskap, søvnforstyrrelser, utbrenthet, selvmord og selvskading, vold i klinisk praksis, etikk, transkulturell psykiatri, konsultasjonspsykiatri og sykmeldingspraksis foruten kapitler om forskjellige behandlingstiltak. Det er mye stoff om utredning og diagnostikk, psykometriske tester, og en del om nevropsykologi og somatiske undersøkelser. Dessuten er det oversikter innen barnepsykiatri og alderspsykiatri inklusive mental retardasjon og demens.

Diagnostikken er for det meste DSM-IVbasert, men boken er velsignet fri for endeløs oppramsing av symptomer. Som ventet $i$ en svensk lærebok er de biologiske aspekter ved psykiske lidelser godt ivaretatt. Imidlertid er det rimelig balanse idet psykososiale teorier og forskjellige psykologiske og sosialpsykiatriske forebyggelses- og behandlingsstrategier får sin plass.

Mange forfattere av en lærebok kan være en fordel ettersom oppgavene blir fordelt $i$ henhold til ekspertise, men ulempen er at fremstillingen gjerne blir noe ulik. Noen av kapitlene er etter min oppfatning for tynne og lemfeldige med litteraturreferanser, mens det er mange eksempler på det motsatte. Slike gode, velintegrerte og oversiktlige kapitler er henholdsvis de om forstemningssyndromer (depresjoner og bipolar lidelse), somatoforme syndromer og dessuten substansrelaterte forstyrrelser (mis- bruk), selv om delirbehandling i det siste eksemplet burde vært fremstilt med mer konkrete anbefalinger med hensyn til medikasjon. Arbeidet med publikasjonen har åpenbart tatt mange år, og ikke alle kapitlene er like oppdatert.

Alt i alt gir imidlertid boken et godt inntrykk. Den kan leses som oppslagsbok og kan trygt anbefales til medisinske studenter, leger og dessuten til andre faggrupper som arbeider innen psykisk helsearbeid.

\section{Stein Opjordsmoen Ilner}

Psykiatrisk divisjon

Oslo universitetssykehus, Ullevål

\section{Pasienthåndbok om rygglidingar - ikkje eit førstevalg}

Jayson MIV.

Forstå vond rygg

132 s, ill. Oslo: Exlibris, 2008. Pris NOK 99 ISBN 987-82-8173-050-2

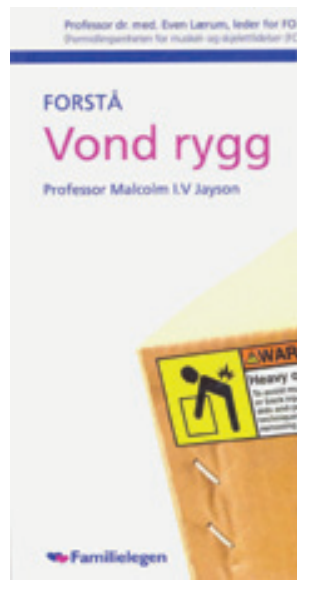

I tillegg til informasjon frå legen eller anna helsepersonell, kan mange ryggpasientar ha god nytte av å lese populærvitskapleg stoff enten på nettet eller på papir. Denne vesle boka kunne ha vore ei god slik informasjonskjelde, og har også som målsetting

å vere eit supplement til andre råd som pasientar får om rygglidingar. Diverre trur eg ikkje at ho innfrir særleg godt.

Boka har eit lite format, har plastomslag og er delvis meint til å brukast som oppslagsbok. Ordlista i registeret er omfattande slik at ein lett skal finne tilbake i teksten. Forstå vond rygg gjev informasjon om anatomi, omtalar dei vanlegaste årsakene til ryggplager og ulike former for utgreiing og terapi. Det er eit eige kapittel om smerte. Råd om eigenomsorg og trening har fått god plass. Det er også god plass i slutten av boka til «Dine sider» der pasienten kan skrive eigne notatar, spørsmål og avtaler. Diverre er sidetilvisningane i sjølve teksten ofte feil. Språket er ujevnt og prega av mange innskot, kommafeil og lange setningar. Teksten kunne ha vore betre gjennomarbeidd. Eg er ikkje overtydd om at omsetjinga er god, men har ikkje lese den engelske originalteksten. Det er ein del faktafeil som skjemmer teksten, både når det gjeld anatomi og terapi. Mellom anna står det at det er vanleg å fjerne heile mellomvirvelskiva ved prolapsoperasjonar. Sidan dette er den vanlegaste ryggoperasjonen, er det synd at slik feilinformasjon vert gjeven. Illustrasjonane er gode, men dei er så dårleg avgrensa frå teksten at dei kunne vere vanskelege å finne igjen når eg bladde om til neste side. Tydelegare rammer omkring illustrasjonane hadde etter mi meining gjeve boka betre layout. Kapittelet om nakkeplager er uhøveleg stort, og språket her er vanskeleg tilgjengeleg med mange framandord (intrusjon, avoidance). Teksten gjev meir grunnlag til uro enn tryggleik for dei som har fått nakkeslengdiagnose.

Sjølv om det neppe er intensjonen, kan boka gje eit inntrykk av at ryggen er svak og at ein må leve forsiktig for unngå «belastningar», «slitasje» og «skader». Innhaldet er nok prega av at første utgave av originalboka kom i 1997. Bøker om dette teamet må vurderast som ferskvare.

Eg trur ikkje at eg vil tilrå mine ryggpasientar denne boka. Etter mi meining gjev «Formidlingsenheten for muskel- og skjelettlidelser» (www.formi.no) mykje betre og meir oppdatert informasjon om rygg. Når ryggen krangler av Åge Indahl var også meir utfordrande og lesverdig for mange av oss som har rygglidingar (1).

Dag M. Soldal

Revmatologisk avdeling

Sørlandet sykehus

Kristiansand

\section{Litteratur}

1. Indahl Å. Når ryggen krangler. Rakkestad: Valdisholm forlag, 2003 